\title{
Work-related Disability among Egyptian Workers
}

\author{
Hoda A. El-Ghamry, Amany S. Mohammad, Dina S. Badran and Mohammad \\ E. Nouri²
}

\footnotetext{
${ }^{1}$ Forensic Medicine and Clinical Toxicology Department, Faculty of Medicine, Cairo University, Cairo, Egypt.

${ }^{2}$ Sudanese Federal Ministry of Health, Sudan.
}

All rights reserved.

\begin{abstract}
Thorough knowledge of the trends of workplace disabilities is essential for the development of strategies for better assessment and fair judgment. The aim of this study was to focus on cases of disability in workplaces presented to the forensic medicine authority in Cairo, Ministry of Justice during 2008 and 2009. The information used was obtained from reports written by Medico Legal Experts (MLE), and then submitted to statistical analysis. There were a total of 142 cases of workplace disabilities in different establishments. Most cases lie between 18 and 34 years of age. Limitation of joint movements was the most frequent type of injury (49.3\%), followed by fractures and nerve, tendon or muscle injuries $(26.8 \%)$ each. Caught by machine was the most frequent event (40\%), followed by falls/slips $(20 \%)$. Hands were the most affected part of the body (28.2\%). After assessment by MLE, the highest number of workplace disabilities fell in the 0 to $20 \%$ range, and presented in 86 victims $(60.6 \%)$. Disabilities due to falls/slips and being hit by object scored the highest rating percentages. Of all current study cases, general establishments recorded $89.2 \%$ where private ones were only $10.8 \%$. This study recommended to revising Egyptian laws regularly, concerning the work accident notification form, for better accident analysis and employees protection and to get suitable compensation in cases of work-related disability.
\end{abstract}

Keywords Workplace, disability, Egyptian, Medico-legal Expert (MLE)

\section{Introduction}

A major part of the general morbidity of the working people is related to work. The goal of making the workers in the world enjoy complete physical and mental health is not yet achieved (WHO, 2006). Work-related injuries are considered a worldwide health problem because they affect a great number of workers, especially young people at productive age. They are also highly disabling, leading to major social and economic consequences (Roberta et al., 2007).

According to the fifth edition of the Guides to the Evaluation of Permanent Impairment, published by the American Medical Association (AMA), disability is defined as "the alteration of an individual's capacity to meet personal, social, or occupational demands because of the impairment" (Cocchiarella et al., 2000). The Florida Impairment Schedule defines impairment as any anatomical or functional abnormality or loss that follows maximal medical improvement (Hunter, 2005). The World Health Organization WHO, (2007) defined disability as temporary or permanent, partial or complete limitation of the activity that results in a difficulty in the performance, or completion of an activity that is considered normal for a human being (Edward, 2008).

Despite the availability of effective interventions to prevent occupational hazards and to protect and promote health at the workplace, large gaps exist between and within countries with regard to the health status of workers and their exposure to occupational risks (Pan American Health Organization PAHO, 2008).

Many workers' compensation systems allow for partial disability, generating a need for the AMA Guides to measure the extent of the impairment as related to normal functional capacity (Edward, 2008). The goal of the disability assessment process is to develop a detailed picture of the individual being evaluated, including; among other factors, medical impairments, residual functional capacities, post injury attitudes and skills, personality characteristics, the environments in which the individual might again live and work, and levels of functioning prior to impairment. Disability evaluation and rehabilitation professionals do not always agree on nomenclature and specific methodologies, and as a result, both the 
meaning and practice of assessing occupational disability vary (Jasen and Stacy, 2009).

In Canada, Breslin et al., (2007) found that the decline in claims was significantly associated with a decline in the proportion of employment in occupations with high physical demands. These findings should generate interest in economic incentives and regulatory policies designed to encourage investment in safer production processes.

\section{Aim of the work}

This work aimed to study the cases of disability in workplaces examined at Forensic Medicine Authority in Cairo through two years (2008 and 2009), to determine the type of injury, the part of the body injured, the direct cause of the event, and the type of occupation and to evaluate the disability rating percentage. Gender and age groups were also taken into consideration.

\section{Subjects \& methods}

This is a retrospective study based on the data collected from the medico-legal reports of workplace disability victims who were presented to the Medico-legal Administration Department of Cairo, Ministry of Justice during the years; 2008 and 2009.

The study included:

1- All those who claimed that their disabilities occurred due to accidents during the course of their work and because of it.

2- Persons on special missions outside the establishment.

3- Accidents occurred in the way to, or from work.

Exclusion criteria

1- Assaults not related to work and suicide attempts.

2- Fatal outcomes.

A data collection sheet (figure 1) was designed according to the available data in the examined medico-legal reports followed by statistical analysis.

\section{Data Collection Sheet}

\section{Personal data:}

- Age:

- Sex:

\section{Work related data:}

- Workers were classified according to work nature into:

a) Professional workers: Highly educated personals (e.g. engineers, managers, teachers ...etc) b) Skilled workers: Have a special skill but not highly educated (e.g. electrician, carpenter ..etc)

c) Non-skilled workers: No special skills (manual workers, laborers...etc)

- Work places were classified into:

a) General: All big establishments, companies and factories

b) Private: Small workplaces with limited resources.

3. Disability data:

- Injury date.

- Injury type.

- Part injured.

- The cause.

- The estimated percent for disability.

\section{Final medico-legal opinion about the claim:}

- True: if it is really a work disability (during the course and because of the work)

- False: if could not be confirmed as work disability.

- Rating percentage: According to the Egyptian rating tables following the social security act no.137 for the year 1978

\section{Figure 1: The data collection sheet used in the current study.}

\section{Statistical Analysis}

The obtained results were recorded and organized for statistical analysis using SPSS software (statistical package for the social science) version 15 (Spriestersbach et al., 2009). 
For quantitative variables, mean /median (as a measure of central tendency), standard deviation/ range, minimum, and maximum (as measures of variability) were presented.

Frequency and percentages were presented for qualitative variables.

Kruskal Wallis test was used to estimate differences in quantitative variables. proportions.

$\mathrm{Z}$ test was used to estimate difference between agreement

Kappa was calculated as a measure of

\section{Results}

In 2008, 59 cases were seen by medico-legal experts (MLE) for the disability assessment. This number increased significantly to 83 in 2009 (table 1).

Among the 142 cases, regarding the gender, there were only 4 females representing $2.8 \%$, while males represented $97.2 \%$. The mean age was $30.81 \pm$ 11.7 years. The youngest worker was only 9 years old; while the oldest was 72 years old.

Most injuries occurred in the age group (18$<25$ ) years where it recorded $30.9 \%$ followed by the age group $(25-<35)$ years in which the percentage was $30.1 \%$. It is noteworthy to mention that the least affected group was the elderly above 60 years $(2.9 \%)$. On the other hand, adolescents below 18 years recorded $7.4 \%$ of all injuries (table 2 ).

Most of the injured workers were non-skilled ones recording $49.3 \%$, followed by skilled workers $46.5 \%$. Only $4.2 \%$ were professionals. The least mean age was among non-skilled workers where it was 29.04 \pm 11.21 years. There was no significant relationship between age and work injury nature (table 3 ).

Regarding the classification of workplace nature and the distribution of cases, of 142 cases data there was missing in records of 3 cases. The injuries in the big (general) establishments recorded $89.2 \%$ while in the small (private) ones; it recorded only $10.8 \%$ (table 4).

Concerning the month in which injury occurred, the highest frequency of injured cases reported was in August (14.1\%) followed by July (13.4\%) and the least was $2.1 \%$ in February (table 5).

Regarding the part of the body injured, hands were the most affected part of the body in workplace disabilities $(28.2 \%)$ followed by the back $(14.1 \%)$ then lower limbs (13.4\%). Multiple organ affection at a time was recorded in $9.2 \%$ of cases. Despite this percentage was not the highest, it was disabling as it involved the head in 3 cases: two were severe with $100 \%$ disability and one was not related to work (figure 2).

Occupational injuries distributed according to the event leading to injury showed in table (6). Caught by machine was the most frequent event $(23.9 \%)$, followed by falls/slips $(14.8 \%)$ then hit by object $(13.4 \%)$.

Figure (3), showed Distribution of injury type among disability cases, where

- Limitation of joint movements were the most frequent type of injury found in 70 cases $(49.3 \%)$ followed by fractures and nerve, tendon or muscle injuries $(26.8 \%)$ each.

- Amputation resulted as workplace disability in 31 cases $(21.8 \%)$.

- Hearing loss as well as foreign body (FB) in soft tissue was the least frequent types of injuries found in 1 case for each $(0.7 \%)$.

Table (7) showed the distribution of injury type according to age groups. Limitation of joint movements was the commonest injury recorded (70 cases) followed by nerve, tendon $\&$ muscle injuries as well as fractures (38 cases for each). They occurred in all age groups up to 60 years. The least injuries recorded were hearing loss, which occurred in the age group $18-<25$ years and foreign body in soft tissue that affected the age group between $25-<35$ years ( 1 case for each).

Elderly ( $>60)$ were mostly affected by amputation and systemic diseases (2 cases for each).

Out of valid claims, forensic assessment by medico-legal expert (MLE) revealed that $75.9 \%$ were confirmed true (injuries due to and in the course of the work), while $24.1 \%$ were not (table 8 ).

Out of 137 cases claiming work-related injuries and according to MLE assessment, 104 cases were workplace injuries (i.e. they were due to and in the course of the work). Ninety eight of these resulted in disabilities and scored a rating percentage (i.e. most workplace injuries were disabling). In addition, there were 33 cases with injuries resulted in disabilities and scored a rating percentage but labeled as not due to work (table 9). The majority scored rating percentage, as measure of agreement (kappa) was significant. Cases where percentage is not determined and/or claim is not confirmed are excluded from this table ( 5 cases). Measure of agreement (Kappa) is 0.737 that means: most cases that confirmed as work disability, the rating percentage was determined

Disability percentage ranges according to MLE assessment were shown in figure (4). The highest percentage of workplace victims' disabilities $(60.6 \%)$ fell in the $(0-20 \%)$ range. The lowest percentage of workplace victims' disabilities $(4.2 \%)$ was found in the disability percentage range $(>60-80 \%)$.

While the complete disability (100\%) group analysis was;

There were 8 victims suffered from complete disability $(100 \%)$, their analysis was as the following:

- One victim suffered from; renal failure, left sided paresthesia, cancer bladder and hypertension. $\mathrm{He}$ claimed that his disability because of stressful nature of the work but forensic assessment revealed no association.

- Two victims suffered from spinal injury, paralysis and incontinence. One fell down from high level on the back, the other involved in transportation injury. 
- One victim suffered from head injury when a heavy object fell on his head complicated by right side paralysis.

- One victim suffered from: amputated fingers in both hands when they were caught by an operating machine.

- One victim suffered from head and eye injuries complicated by brain atrophy.

- One victim suffered from: fractures in pelvis and both lower limbs complicated by paraplegia.

- One victim suffered from bilateral eye injury complicated by loss of vision.

Table (10), showed the relation between injured parts and their disability percentage range. The 0 to $20 \%$ range was most frequently scored by extremities (67.6\%) and back (19.5\%) disabilities. Most severe disabilities scoring $>80 \%$ resulted mainly from multiple body parts affection.

Table (11), showed the relation between main types of injuries and their disability percentage range. The most frequent injury type that scored $0-20 \%$ disability was limitation of joint movement (42 cases) followed by fracture (25 cases). Again Limitation of joint movement (3cases) and nerve, tendon or muscle injury ( 3 cases) were the most disabling scoring $>80 \%$.

Relation between event and age group was shown in table (12). Relatively old aged (median=43.5 years) were more prone to be disabled by sitting or standing for long time during their work. $\mathrm{P}$ value= 0.054 which is $>0.05$ which was statistically insignificant.

Table (13) showed the rating percentage difference according to the cause (event). Falls/slips and hit by object were the most disabling events scoring $32.06+27.8 \%$ and $32.18+29.9 \%$ respectively. Sitting or standing for long time was the least $(7.50+12.55 \%)$. $\mathrm{P}$ value is $<0.005$ which was statistically significant.

The Relation between rating percentage and different age groups were showed in table (14). Elderly ( $>60$ years) are more liable to severe disabilities scoring $(31.44+9.72 \%)$. Those aging $35-<45$ years of age scored the least rating percentage $(16.39+17.24 \%)$. $\mathrm{P}$ value $=0.373$ which is $>0.05$ which was statistically insignificant.

Table (1): Frequency of workplace disability claims in each year.

\begin{tabular}{|c|c|c|c}
\hline Year & No. & \% & P \\
\hline 2008 & 59 & 41.5 & \multirow{2}{*}{$<0.05$} \\
\hline 2009 & 83 & 58.5 & \\
\hline Total & 142 & 100 & \\
\hline
\end{tabular}

Table (2): Frequency of cases regarding different age groups.

\begin{tabular}{|c|c|c|c|}
\hline \multicolumn{2}{|c|}{ Age group (years) } & Frequency & Valid \% \\
\hline \multirow[t]{7}{*}{ Valid } & $<18$ & 10 & 7.4 \\
\hline & $18-<25$ & 42 & 30.9 \\
\hline & $25-<35$ & 41 & 30.1 \\
\hline & $35-<45$ & 28 & 20.6 \\
\hline & $45-60$ & 11 & 8.1 \\
\hline & $>60$ & 4 & 2.9 \\
\hline & Total & 136 & 100.0 \\
\hline \multicolumn{2}{|c|}{ Missing System* } & 6 & \\
\hline \multicolumn{2}{|l|}{ Total } & 142 & \\
\hline
\end{tabular}

Table (3): The distribution of cases and mean age + SD according to work nature.

\begin{tabular}{|l|c|c|c|c}
\hline Work nature & Frequency & Percent & Mean age +SD (years) & P value \\
\hline Non-skilled & 70 & 49.3 & $29.04+11.213$ & \multirow{2}{*}{0.125} \\
\hline Professionals & 6 & 4.2 & $36.17 \pm 7.653$ & \\
\hline Skilled & 66 & 46.5 & $32.17 \pm 12.478$ & \\
\hline Total & 142 & 100.0 & & \\
$P>0.05$ not significant
\end{tabular}

Table (4): Classification of workplace nature into general and private sectors and their distribution.

\begin{tabular}{|l|l|c|c|}
\hline \multicolumn{2}{|c|}{ Sector } & Frequency & Valid Percent \\
\hline \multirow{3}{*}{ Valid } & General & 124 & 89.2 \\
\cline { 2 - 4 } & Private & 15 & 10.8 \\
\cline { 2 - 4 } & Total & 139 & 100.0 \\
\hline \multicolumn{2}{|l|}{ Missing System* } & 3 & - \\
\hline \multicolumn{2}{|c|}{ Total } & 142 & - \\
\hline
\end{tabular}

* Data were missing in records of 3 cases (i.e. total no. of cases $=139$ ) 
Table (5): Workplace disability cases percentage according to the month in which injury occurred.

\begin{tabular}{|l|c|c|}
\hline \multicolumn{1}{|c|}{ Month } & Frequency & Percent (\%) \\
\hline January & 16 & 11.3 \\
\hline February & 3 & 2.1 \\
\hline March & 11 & 7.7 \\
\hline April & 10 & 7.0 \\
\hline May & 12 & 8.5 \\
\hline June & 12 & 8.5 \\
\hline July & 19 & 13.4 \\
\hline August & 20 & 14.1 \\
\hline September & 14 & 9.9 \\
\hline October & 9 & 6.3 \\
\hline November & 6 & 4.2 \\
\hline December & 10 & 7 \\
\hline Total & 142 & 100.0 \\
\hline
\end{tabular}

Table (6): Occupational injuries distributed according to the event leading to injury.

\begin{tabular}{|l|c|c|}
\hline \multicolumn{1}{|c|}{ Cause of injury } & Frequency & $\mathbf{\%}$ \\
\hline Stress & 18 & 12.7 \\
\hline Burn & 7 & 4.9 \\
\hline Falls/slips & 21 & 14.8 \\
\hline Caught by machine & 34 & 23.9 \\
\hline Hard activity & 5 & 3.5 \\
\hline Hit by object & 19 & 13.4 \\
\hline Lifting heavy objects & 7 & 4.9 \\
\hline Sitting or standing for long time & 6 & 4.2 \\
\hline Explosion & 5 & 3.5 \\
\hline Transportation injury & 6 & 4.2 \\
\hline Repeated exposure & 5 & 3.5 \\
\hline Assault & 1 & 0.7 \\
\hline Overcrowding & 1 & 0.7 \\
\hline Neglect & 1 & 0.7 \\
\hline Multiple events & 4 & 2.8 \\
\hline Unknown & 2 & 1.4 \\
\hline Total & $\mathbf{1 4 2}$ & $\mathbf{1 0 0 . 0}$ \\
\hline
\end{tabular}

Table (7): Distribution of injury type according to age groups.

\begin{tabular}{|c|c|c|c|c|c|c|c|c|c|c|c|c|c|}
\hline \multirow{3}{*}{ Injuries } & \multirow{3}{*}{$\begin{array}{c}\text { Total } \\
\text { No. }\end{array}$} & \multicolumn{12}{|c|}{ Age categories (years) } \\
\hline & & \multicolumn{2}{|c|}{$<18$} & \multicolumn{2}{|c|}{$18-<25$} & \multicolumn{2}{|c|}{$25-<35$} & \multicolumn{2}{|c|}{$35-<45$} & \multicolumn{2}{|c|}{$45-60$} & \multicolumn{2}{|c|}{$>60$} \\
\hline & & No. & $\%$ & No. & $\%$ & No. & $\%$ & No. & $\%$ & No. & $\%$ & No. & $\%$ \\
\hline Fractures & 38 & 4 & 10.5 & 9 & 23.6 & 16 & 42.1 & 5 & 13.1 & 4 & 10.5 & 0 & 0 \\
\hline Nerve, tendon, muscle & 38 & 5 & 13.1 & 13 & 34.2 & 13 & 34.2 & 4 & 10.5 & 3 & 7.8 & 0 & 0 \\
\hline Muscle atrophy & 4 & 0 & 0 & 2 & 50 & 1 & 25 & 0 & 0 & 1 & 25 & 0 & 0 \\
\hline Pain & 10 & 1 & 10 & 1 & 10 & 2 & 20 & 4 & 40 & 1 & 10 & 0 & 0 \\
\hline Paralysis, paresthesia & 12 & 2 & 16.7 & 5 & 41.7 & 2 & 16.7 & 2 & 16.7 & 1 & 8.3 & 0 & 0 \\
\hline Limitation of joint movement & 70 & 5 & 7.1 & 21 & 30.0 & 20 & 28.6 & 14 & 20.0 & 8 & 11.4 & 0 & 0 \\
\hline Amputation & 31 & 2 & 6.4 & 10 & 32.2 & 10 & 32.2 & 5 & 16.1 & 1 & 3.2 & 2 & 6.4 \\
\hline Eye injury & 8 & 1 & 12.5 & 2 & 25.0 & 4 & 50.0 & 1 & 12.5 & 0 & 0 & 0 & 0 \\
\hline FB on external eye & 2 & 0 & 0 & 1 & 50 & 0 & 0 & 1 & 50 & 0 & 0 & 0 & 0 \\
\hline FB in soft tissue & 1 & 0 & 0 & 0 & 0 & 1 & 100 & 0 & 0 & 0 & 0 & 0 & 0 \\
\hline Spinal injury & 3 & 1 & 33.3 & 1 & 33.3 & 1 & 33.3 & 0 & 0 & 0 & 0 & 0 & 0 \\
\hline Incontinence & 3 & 1 & 33.3 & 1 & 33.3 & 1 & 33.3 & 0 & 0 & 0 & 0 & 0 & 0 \\
\hline Systemic diseases & 21 & 1 & 4.8 & 4 & 19.0 & 3 & 14.3 & 8 & 38.0 & 3 & 14.3 & 2 & 9.5 \\
\hline Head injury & 2 & 0 & 0 & 1 & 50.0 & 0 & 0 & 1 & 50.0 & 0 & 0 & 0 & 0 \\
\hline loss of vision & 7 & 1 & 14.2 & 2 & 28.6 & 2 & 28.6 & 2 & 28.6 & 0 & 0 & 0 & 0 \\
\hline Hearing loss & 1 & 0 & 0 & 1 & 100 & 0 & 0 & 0 & 0 & 0 & 0 & 0 & 0 \\
\hline Skin disfigurement & 8 & 1 & 12.5 & 4 & 50.0 & 2 & 25.0 & 0 & 0 & 1 & 12.5 & 0 & 0 \\
\hline Psychological & 5 & 0 & 0 & 2 & 40.0 & 3 & 60.0 & 0 & 0 & 0 & 0 & 0 & 0 \\
\hline Others & 6 & 0 & 0 & 1 & 16.6 & 4 & 66.7 & 0 & 0 & 1 & 16.6 & 0 & 0 \\
\hline
\end{tabular}


Table (8): Distribution of cases according to claim.

\begin{tabular}{|l|l|c|c|}
\hline \multicolumn{2}{|c|}{ Claim } & Frequency & Valid Percent \\
\hline \multirow{3}{*}{ Valid } & False & 34 & 24.1 \\
\cline { 2 - 4 } & True & 107 & 75.9 \\
\cline { 2 - 4 } & Total & 141 & 100.0 \\
\hline \multicolumn{2}{|l|}{ Missing System* } & 1 & - \\
\hline \multicolumn{2}{|l}{ Total } & 142 & - \\
\hline
\end{tabular}

* There was one case could not be confirmed.

Table (9): Relation between claim and disability percentage recorded.

\begin{tabular}{|l|l|c|c|c|}
\hline \multirow{2}{*}{} & \multicolumn{3}{|c|}{ Claim } & Total \\
\cline { 3 - 5 } \multicolumn{2}{|c|}{ Rating percent } & False & True & \\
\cline { 3 - 5 } & NO count & 26 & 6 & 32 \\
\cline { 2 - 4 } & YES count & 7 & 98 & 105 \\
\cline { 2 - 4 } & Total count & 33 & 104 & 137 \\
\hline \multicolumn{2}{|c|}{} & Value & P & \\
\hline Measure of Agreement & Kappa & .737 & 0.000 & \\
\hline No. of Valid Cases & 137 & & \\
\hline
\end{tabular}

Table (10): The relation between injured parts and their disability percentage range.

\begin{tabular}{|c|c|c|c|c|c|c|c|c|c|c|c|c|c|c|c|c|c|c|}
\hline $\begin{array}{l}\text { Part } \\
\text { injured }\end{array}$ & & and & $\mathbf{B a}$ & ck & & $\begin{array}{l}\text { wer } \\
\text { nb }\end{array}$ & & & $\begin{array}{r}\text { Mu } \\
\text { p }\end{array}$ & $\begin{array}{l}\text { iple } \\
\text { ts }\end{array}$ & Ey & ye & $\begin{array}{r}\text { B } \\
\text { sys }\end{array}$ & & $\mathbf{O t}$ & ners & & tal \\
\hline $\begin{array}{l}\text { Disability } \\
\%\end{array}$ & No. & $\%$ & No. & $\%$ & No. & $\%$ & No. & $\%$ & No. & $\%$ & No. & $\%$ & No. & $\%$ & No. & $\%$ & No. & $\%$ \\
\hline $0-20 \%$ & 24 & 48.2 & 17 & 19.5 & 13 & 14.9 & 4 & 4.5 & 5 & 5.7 & 3 & 3.4 & 11 & 12.6 & 10 & 11.4 & 87 & 60.6 \\
\hline$>20-40 \%$ & 10 & 35.7 & 0 & 0 & 3 & 10.7 & 5 & 17.8 & 1 & 3.5 & 5 & 17.8 & 2 & 7.1 & 2 & 7.1 & 28 & 19.7 \\
\hline$>40-60 \%$ & 5 & 35.7 & 1 & 7.1 & 3 & 21.4 & 1 & 7.1 & 2 & 14.2 & 0 & 0 & 0 & 0 & 2 & 14.2 & 14 & 9.9 \\
\hline$>60-80 \%$ & 0 & 0 & 0 & 0 & 0 & 0 & 3 & 60 & 1 & 20 & 0 & 0 & 1 & 20 & 0 & 0 & 5 & 4.2 \\
\hline$>80-100 \%$ & 1 & 12.5 & 2 & 25 & 0 & 0 & 0 & 0 & 4 & 50 & 1 & 12.5 & 0 & 0 & 0 & 0 & 8 & 5.6 \\
\hline
\end{tabular}

Table (11): Relations between main types of injuries and their disability percentage range.

\begin{tabular}{|c|c|c|c|c|c|c|c|c|}
\hline \multirow{2}{*}{$\begin{array}{l}\text { Injury type } \\
\text { Disability \% }\end{array}$} & \multicolumn{2}{|c|}{ Fracture } & \multicolumn{2}{|c|}{$\begin{array}{c}\text { Nerve, tendon or muscle } \\
\text { injury }\end{array}$} & \multicolumn{2}{|c|}{ Limitation of joint movement } & \multicolumn{2}{|c|}{ Amputation } \\
\hline & No. & $\%$ & No. & $\%$ & No. & $\%$ & No. & $\%$ \\
\hline $0-20 \%$ & 25 & 65.7 & 22 & 57.8 & 42 & 60 & 17 & 54.8 \\
\hline$>20-40 \%$ & 4 & 10.5 & 7 & 18.4 & 14 & 20 & 6 & 19.3 \\
\hline$>40-60 \%$ & 5 & 13.1 & 4 & 10.5 & 8 & 11.4 & 6 & 19.3 \\
\hline$>60-80 \%$ & 2 & 5.2 & 2 & 5.2 & 3 & 4.3 & 1 & 3.2 \\
\hline$>80-100 \%$ & 2 & 5.2 & 3 & 7.8 & 3 & 4.3 & 1 & 3.2 \\
\hline
\end{tabular}

Table (12): the Relation between event and age group.

\begin{tabular}{|c|c|c|}
\hline Cause & Median (year) & Mean age (year) \\
\hline Burn & \multirow[t]{7}{*}{26.5} & $29.23+8.786$ \\
\hline Fall from height & & $26.72+8.723$ \\
\hline Caught by machine & & $29.88+14.25$ \\
\hline Hard activity & & $34.57 \pm 14.49$ \\
\hline Others & & $27.39+9.611$ \\
\hline Hit by object & & $31.44+9.716$ \\
\hline Lifting heavy objects & & $34.88+4.291$ \\
\hline Sitting or standing for long time & 43.5 & $40.50+9.834$ \\
\hline
\end{tabular}

$P$ value $=0.054$ which is $>0.05$ which was statistically insignificant 
Table (13): the rating percentage difference according to the cause.

\begin{tabular}{|l|c|c|c|}
\hline \multicolumn{1}{|c|}{ Cause } & Mean rating \%+SD & Median rating \% & Range of rating \% \\
\hline Burn & $19.17+23.5$ & 10.00 & $0-65$ \\
\hline Falls/slips & $32.06+27.8$ & 20.00 & $7-100$ \\
\hline Caught by machine & $28.65+22.9$ & 20.00 & $5-100$ \\
\hline Hard activity & $12.27+25.2$ & 0 & $0-100$ \\
\hline Hit by object & $32.18+29.9$ & 20 & $0-100$ \\
\hline Lifting heavy objects & $16.25+11.877$ & 17.50 & $0-35$ \\
\hline Sitting or standing for long time & $7.50+12.55$ & 0 & $0-30$ \\
\hline Others & $27.63+24.9$ & 35.00 & $0-75$ \\
\hline
\end{tabular}

$P$ value is $<0.005$ which was statistically significant.

Table (14): Relation between rating percentage and different age groups.

\begin{tabular}{|l|c|c|}
\hline Age group (years) & Median rating \% & Mean rating percentage \\
\hline$<18$ & 30.00 & $28.6 \pm 20.4$ \\
\hline $18-24$ & 20.00 & $30.19 \pm 27.4$ \\
\hline $25-34$ & 15 & $25.36 \pm 28.44$ \\
\hline $35-44$ & 11.50 & $16.39 \pm 17.24$ \\
\hline $45-60$ & 20.82 & $17.42 \pm 20.82$ \\
\hline$>60$ & 18.50 & $31.44 \pm 9.716$ \\
\hline
\end{tabular}

$P$ value $=0.373$ which is $>0.05$ which was statistically insignificant.

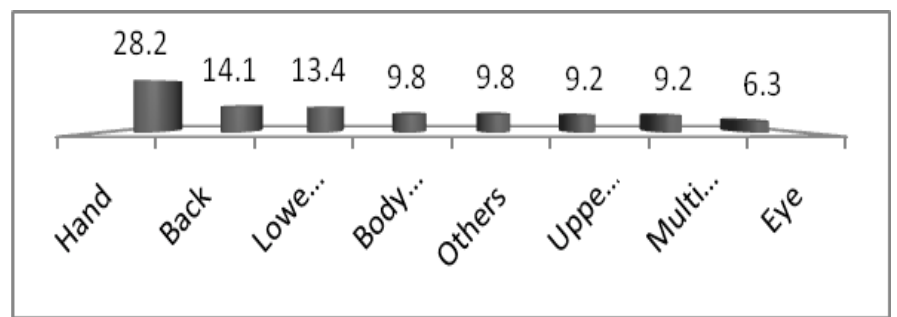

Figure (2): Percentage of cases according to part of the body injured: Lowe=lower limb, Body= body systems, Uppe= upper limb, Multi= multiple organs.

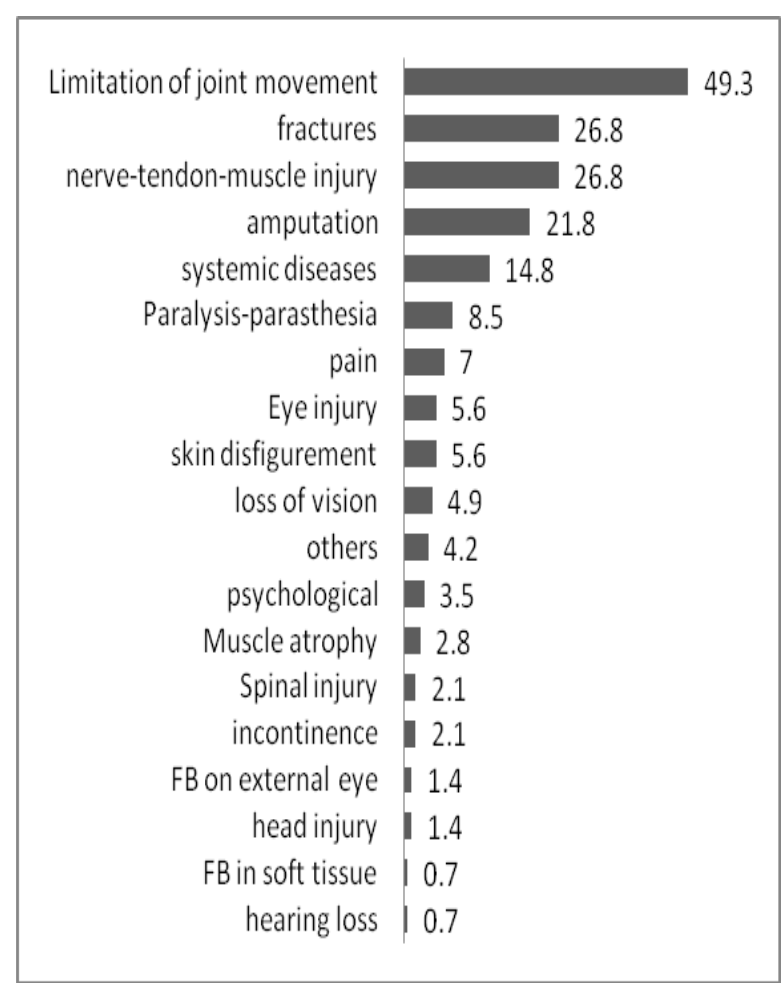

Figure (3): Distribution percentage of injury type among disability cases: $F B=$ foreign body. 


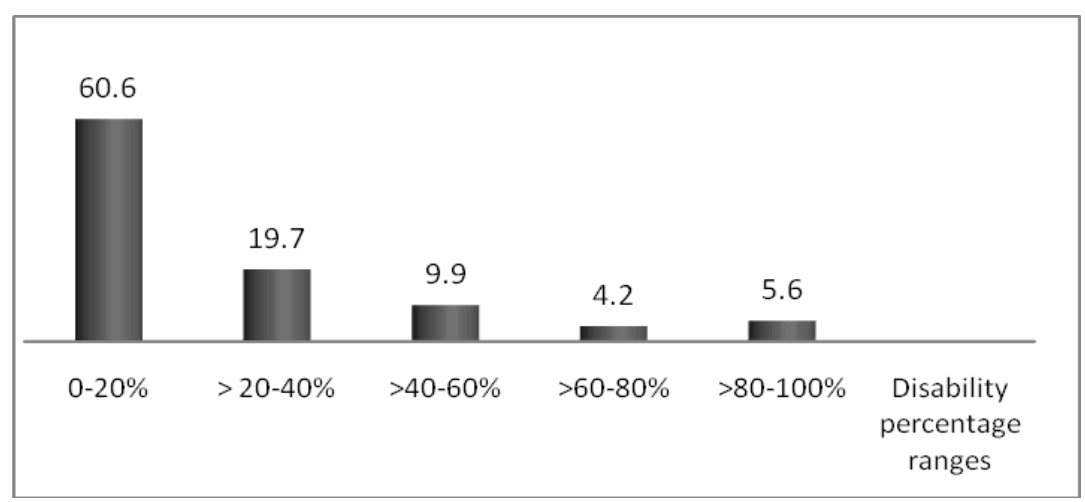

Figure (4): Disability percentage ranges (According to MLE assessment).

\section{Discussion}

Bureau of Labour Statistics survey, workers compensation, medical records and physician reporting system are possible channels for reporting workplace injuries and illness but still under-reporting can occur (Azaroff et al, 2002).

Schulte, (2005) stated that the magnitude of occupational disease and injury burden is significant but underestimated. There is a need for an integrated approach to address these underestimates.

Before discussing the findings of the current study, limitations of the study are to be mentioned. First of all, studies that have focused on disability in workplaces in developing countries are scarce. Therefore a comparison of the results with the findings of other studies conducted in similar environments was difficult. Other general injury studies have mentioned workplace injuries, but detailed analysis was lacking. Also, the role of MLE in assessing disability is rarely discussed.

In the present study, as regarding the sex, females represented $2.8 \%$ of cases of occupational injury and there was a predominance of male gender (97.2\%). All studies from developing or developed countries agree with the current study result. In a study in AL-Ain district in Emirate, males accounted for $98 \%$ of injuries (Barss et al., 2009). In Iran, among 1180 cases with workplace injuries, $95 \%$ of them were males (Roudsari and Ghodsi, 2005). In Egypt, according to the statistical report for occupational injuries for the year 2007, about $93 \%$ of workplace injuries were among males (CAPMAS, 2008). Jin et al., (2010) agreed with us and concluded that Injury frequency was more associated with male gender. This finding was explained by Driscoll et al., (2005), who reported that men occupy a large majority of hazardous jobs and so has a higher probability to be injured. Furthermore, in developing countries like Egypt; the majority of the workforce consists of males, making them more liable for injuries than females' counterparts.

Regarding different age groups, in the current study, one third of the injuries occurred in the age group $18-<25$ years representing $30.9 \%$. Besides, there were $7.4 \%$ below 18 years old.
This result agreed with Driscoll et al., (2005) who reported that younger workers (aged 15-24) are significantly more likely to suffer non-fatal workplace accidents than their older colleagues. Again, Chau et al, (2002) found that a higher risk was only found in subjects younger than 30 years.

Young age is associated with a lack of experience which predisposes to the occurrence of injuries; it could also be associated with a lack of job knowledge and know-how (Salminen, 1994). Takala, (1999) also explained that the causes for the increase amongst young workers are various, including their lack of work experience and understanding of workplace hazards. As most of the young employees, in a study presented by Nakata et al., (2006) required acquiring skills on the job but without training; they have a higher risk of being injured.

Contrary to the present study results, CDC, (2007) stated that in USA National Electronic Injury Surveillance System (NEISS) report about workplace injuries in the year 2004; Workers aged 25-54 years accounted for $70 \%$ of all injuries/illnesses.

Concerning work nature, in the current study, professionals represented only $4.2 \%$ while skilled and non-skilled workers were at high risk recording $46.5 \%$ and $49.3 \%$ respectively. This was consistent with the results of the study done by Bhattacherjee et al., (2003) who stated that the job category made the highest contribution to injury involvement; laborers, farmers, craftsmen and tradesmen had the highest risk, and employees and technicians also had greater risk than executives, intellectual professionals. This also was in agreement with d'Errico et al., (2007).

Concerning the injury frequency's seasons in the current study, the highest frequency of injured cases reported in August (14.1\%) followed by July (13.4\%) and the least was in February $(2.1 \%)$.

This agreed with Morabito et al., (2006) who explained this by thermal effects of hot weather which cause stressful behavior and decreased concentration. This was not the case in CAPMAS, (2009) where most injuries were in January (9.8\%) and the least were in December $(5.9 \%)$. 
As far as the event leading to injury is concerned, the most frequent event of the current study was Caught by machine ( $40 \%)$ followed by falls/slips $(20 \%)$ then being hit by object (13.4\%).

These findings agreed with the data on serious workplace accidents in three years from the Aegean Region of Turkey showed that $35.6 \%$ of cases were due to caught in, under or between something, followed by fall $21 \%$ and then collision against or by object (15\%) (Ergör et al., 2003). In consistent with this, in USA NEISS report about workplace injury and illness, in table of events leading to injury collision against a part of machine was the most frequent cause (CDC, 2007). In contrast, the events were arranged in an Emirate study as follows: External causes of work related injuries included falls $51 \%$, falling objects $15 \%$, powered machines $11 \%$, animal-related $7 \%$ and burns $6 \%$ (Barss et al., 2009). A little bit different results were noticed in a study based on an emergency department injury surveillance system in Managua, Nicaragua where $(80 \%)$ of the recorded work related injuries were due to falls, blunt objects trauma (28\%), and stabs/cuts (23\%) (Noe et al., 2004).

Regarding type of injury, the present study showed that Limitation of joint movements was the most frequent type of injury representing (49.3\%) followed by fractures $(26.8 \%)$ and nerve, tendon or muscle injuries (26.8\%). Unfortunately, amputation recorded $(21.8 \%)$.

In partial agreement with these results, the analysis of nature of injury in a study examining the circumstances and nature of the workplace injuries in Isfahan Steel Company revealed that fracture frequency was $30.8 \%$ but had the greatest frequency of injuries (Maryam et al., 2009). Similarly, in 2001 in Michigan, (41\%) of work-related injury hospitalizations were due to fracture of an upper or lower extremity (Stanbury, et al., 2003). The finding in this study is not consistent with the national surveillance of occupational injuries in Nicaragua, in 2004, where the most frequent workplace injuries were bruises $(41 \%)$ followed by wounds $(25 \%)$ (Noe et al., 2004).

As far as injured part is concerned, hands were the most affected in workplace disabilities $(28.2 \%)$ followed by the back $(14.1 \%)$ then lower limbs (13.4\%).

This is agreed with Trybus and Guzik, (2004) who reported that hand injuries are the most frequent body traumas sustained at work. While in their cohort study, Craig et al, (2006) gave some credence to these findings. The most injured body parts included lower extremities (28.6\%), upper extremities $(27.2 \%)$, back $(25.9 \%)$, and head/face/eyes (6.8\%). No much difference was noticed in a study in USA among Hispanic and foreign born workers injured workers .Frequency followed this order: upper extremity injury, head and neck injury, lower extremity and trunk injury, respectively (Forst, et al. 2010).
Discussing events leading to injury in relation to age in the current work, it was found that disability among younger age groups (median $=26.5$ years) occurs mainly when they are caught by a machine while old aged (median $=43.5$ years) are more prone to be disabled by sitting or standing for long time during their work.

Chau, et al., (2002) noted a higher injury risk among workers $<30$ years old due to handling materials/machine parts during assembly, using hand tools and collision with/by moving objects or vehicles, whereas among older ages (especially those aged 50-55 years), there was a higher injury risk due to fall on same level or to lower level, handling materials/machine parts during assembly, lifting/handling objects or equipment, collision with/by moving objects or vehicles, and using hand tools. Moreover, Jovica et al., (2004), reported that when injuries do occur, older workers are usually more severely hurt.

Concerning rating percentage, the highest number of workplace victims' disabilities fell in the 0$20 \%$ range presented in 86 victims $(60.6 \%$ of cases $)$. The lowest number of workplace victims' disabilities $(6$ victims) was found in the disability percentage range $(>60-80 \%)$. We found that multiple body parts affection despite being not frequent but caused high scores in rating percentage $(80-100 \%)$ this is due to summation of disability scores for all organs affected.

This agreed with Welch et al., (2005) study which revealed that about $10 \%$ of the injured workers had two injury diagnoses, sometimes to different body parts. Therefore, some workers are counted in more than one category, and the percentages add up to more than $100 \%$. Elleuch et al., (2004) have conducted a similar retrospective study to 242 files examined by Tunis medical board authorized to set out the permanent disability rate resulting from industrial accidents and occupational diseases, but their study was restricted to lumbar back accidents. The present study showed that most back injuries scored a rate between 0 to $20 \%$. While -in the Tunisian study- the average rate of permanent disability was of $8 \%$.

In the present study, the relation between rating percentage and different age groups showed that elderly ( $>60$ years) are more liable to severe disabilities while those between 35 and 44 years of age scored the least rating percentage. In a statistically significant relation between events and rating percentage, we found that falls/slips and hit by object were the most disabling events while sitting or standing for long time was the least. Jin et al., (2010) found that severity of injury is related mostly to powered machine use. In 2001, in Michigan, the leading causes of work-related disabilities of high rating percentage were; falls, traffic crashes, burns, machinery, electric shocks, and assaults (Stanbury et al., 2003). 
In the current study, comparing number of claims in 2008 and 2009, workplace disability claims have increased by $17 \%$ in 2009.

More than three quarter of all cases were true claims according to MLA (i.e. they were due and in the course of the work).The majority scored rating percentage (i.e. most workplace injuries were disabling). Measure of agreement (kappa) was significant.

In contrast to Tasha, (2006) that determined accepted disabling claims in 5 years period by only $18 \%$. This may be due to detailed accident analysis and complex compensation rules. Wind et al., (2009) found that the physicians most often changed their judgment regarding the claimant's work ability when taking the FCE (Functional Capacity Evaluation) protocol into account.

Of all current study cases, general establishments recorded $89.2 \%$ where private ones were only $10.8 \%$.

A possible explanation is that despite the employee may have the right to apply for workers' compensation; nothing would prevent the employer from discharging or disciplining the injured employee for pursuing compensation. For fear of this possibility, an employee may be less likely to pursue compensation, or even medical attention, for his injuries" (Colledge et al., 2009).

Developing countries, where the rate of accidents has been increasing, face particular challenges. There, most workers are in the informal economy where work-related accidents, disease and death are likely to be unrecorded (ILO, 2009).

In Egypt, the accurate and reliable recording system for cases of work-injuries is still lacking. There is a clear need for better and more reliable data on the nature, causes and extent of injuries. Rating tables approved by social insurance laws are used by medico legal experts in an attempt to reach clear and fair judgment, but still individual variation among examiners affects assessment.

\section{Recommendations}

This study recommends modifying and revising Egyptian laws, concerning "the social security act No.79 for the year 1975" demonstrating "the work accident notification form", in comparison to work accident analysis forms in US department of labour, for better accident analysis and employees protection.

In addition, the present work recommends improving the forensic examination and assessment of workers disabilities due to workplace-accidents in Egypt, in order to make workers compensation claims, in front of the civil courts, more subjective, obvious, and fair.

Hopefully, these findings could stimulate and guide future research and intervention work focusing on this major problem from forensic point of view.

\section{Acknowledgment}

It is a pleasure to convey thanks to the institute of forensic medicine, Ministry of Justice- Egypt for the indispensable support to achieve this study.

\section{References}

Azaroff LS, Levenstein C and Wegman DH (2002): Occupational injury and illness surveillance: conceptual filters explain underreporting. Am. J. Public Health. 92 (9):1421-9.

Barss P, Addley K, Grivna M et al., (2009): Occupational injury in the United Arab Emirates: epidemiology and prevention. Occup. Med. 59 (7): 493-8.

Bhattacherjee A, Chau N, Sierra CO et al., (2003): Relationships of job and some individual characteristics to occupational injuries in employed people: a community-based study. J. Occup. Health. 45 (6): 382-91.

Breslin FC, Tompa E, Mustard C et al., (2007): Association between the decline in workers' compensation claims and workforce composition and job characteristics in Ontario, Canada. Am. J. Public Health. 97 (3): 453-5.

Central Agency for Public Mobilization and Statistics (CAPMAS) (2008): Annual report of occupational injuries in governmental and private sectors workplaces, Cairo, Egypt. (http://www.capmas.gov.eg/default.aspx).

Central Agency for Public Mobilization and Statistics (CAPMAS) (2009): Annual report of occupational injuries in governmental and private sectors workplaces, Cairo, Egypt. (http://www.capmas.gov.eg/default.aspx).

Centers for Disease Control and Prevention (CDC) (2007): Non-fatal occupational injuries and illnesses--United States, 2004. Morb. Mortal Wkly Rep. 56 (16): 393-7.

Chau N, Mur JM, Benamghar L et al., (2002): Relationship between some individual characteristics and occupational accidents in the construction industry: A case-control study on 880 victims of accidents occurred during a two-year period. J. Occup. Health. 44 (3): 131-139.

Cocchiarella L, Turk MA and Andersson G (2000): Improving the evaluation of permanent impairment. JAMA. 283 (4): 532-3.

Colledge A, Hunter B, Bunkall LD et al., (2009): Impairment rating ambiguity in the United States: the Utah Impairment Guides for calculating workers' compensation impairments. J. Korean Med. Sci. 24 (2): 232 41.

Craig BN, Congleton JJ, Kerk CJ et al., (2006): Personal and non-occupational risk factors 
and occupational injury/illness. Am. J. Ind. Med. 49 (4): 249-60.

d'Errico A, Punnett L, Cifuentes M et al., (2007): Promoting Healthy and Safe Employment In Healthcare Research Team. Hospital injury rates in relation to socioeconomic status and working conditions. Occup Environ Med. 64 (5): 325-33.

Driscoll T, Takala J, Steenland K et al., (2005): Review of estimates of the global burden of injury and illness due to occupational exposures. Am. J. Ind. Med. 48 (6): 491-502.

Edward BH (2008): Impairment rating and disability determination, www.emedicine.com/ pmr/ topic170.

Elleuch M, Sahli H, Amira C et al., (2004): Medicolegal aspects of occupational lumbar back accidents. Tunis Med. 82 (10): 914-8.

Ergör OA, Demiral Y and Piyal YB (2003): A significant outcome of work life: occupational accidents in a developing country, Turkey $\mathrm{J}$. Occup. Health. 45 (1): 74-80.

Forst L, Avila S, Anozie S et al., (2010): Traumatic occupational injuries in Hispanic and foreign born workers. Am. J. Ind. Med. 53 (4): 34451.

Hunter OK (2005): Impairment Rating of Neuromusculoskeletal Conditions, www.emedicine.medscape.com/article/31442 0 .

International Labour Organization ILO (2009): ILO standards on occupational safety and health. Promoting a safe and healthy working environment International Labour Conference, www.ilo.org.

Jasen MW and Stacy AP (2009): Assessing Occupational Disability Following Trauma and Impairment, In: Assessing Impairment from Theory to practice, Goldstein $\mathrm{S}$ and Naglieri J (eds), LLC, New York USA, Ch 11. pp. 143-154.

Jin K, Lombardi DA, Courtney TK et al., (2010): Patterns of work-related traumatic hand injury among hospitalized workers in the People's Republic of China. Inj. Prev.16 (1): 42-9.

Jovica J, Aranđelović M and Jovanović M (2004): Multidisciplinary Aspects of Occupational Accidents and Injuries. Working and Living Environmental Protection. 2 (4): 325-333.

Maryam AM, Alireza H, Fazlollah G et al., (2009): Occupational Injuries in Isfahan Steel Company During 2001-2006. European Journal of Scientific Research. 31 (4): 546-52.

Morabito M, Cecchi L, Crisci A et al., (2006): Relationship between work-related accidents and hot weather conditions in Tuscany (central Italy). Ind. Health. 44 (3): 458-64.

Nakata A, Ikeda T, Takahashi M et al., (2006): The prevalence and correlates of occupational injuries in small-scale manufacturing enterprises. J. Occup. Health. 48 (5): 366-76.

Noe R, Rocha J, Clavel-Arcas C et al., (2004): Occupational injuries identified by an emergency department based injury surveillance system in Nicaragua. Inj. Prev. 10 (4): 227-32.

Pan American Health Organization PAHO (2008): World Day for Safety and Health at Work: My life, my work, my safe work: Managing risk in the work environment, www.paho.org/English/D/DRemark_Worker H_eng.htm.

Roberta N, Ana Maria C, Lefèvre C et al., (2007): Knowledge and practices by adolescents in preventing occupational injuries: a qualitative study. Rev. Saúde Pública. 41 (3)

Roudsari BS and Ghodsi M (2005): Occupational injuries in Tehran. Injury. 36 (1): 33-9.

Salminen ST (1994): Epidemiological analysis of serious occupational accidents in southern Finland. Scand. J. Soc. Med. 22 (3): 225-7.

Schulte PA (2005): Characterizing the burden of occupational injury and disease. J. Occup. Environ. Med. 47 (6): 607-622.

Social insurance law No. 79 (1975): modified by the law 25, 1977, www.ilo.org.

Spriestersbach A, Röhrig B, du Prel JB et al., (2009): Descriptive statistics: the specification of statistical measures and their presentation in tables and graphs. Dtsch Arztebl Int., 106 (36): 578-83.

Stanbury M, Reilly MJ and Rosenman KD (2003): Work-related amputations in Michigan, 1997. Am. J. Ind. Med. 44 (4): 359-67.

Takala J (1999): Global estimates of fatal occupational accidents. Epidemiology. 10 (5): 640-6.

Tasha H (2006): Violence in the Workplace: Accepted Disabling Claims due to Assaults and Violent Acts, Oregon, 2001-2005, www.cbs.state.or.us.

Trybus M and Guzik P (2004): Occupational hand injuries. Med Pr. 55 (4): 341-4.

Welch LS, Hunting KL and Murawski JA (2005): Occupational injurers among construction workers treated in a major metropolitan emergency department in the United States. Scand. J. Work Environ. Health. 2: 11-21.

WHO (2006): Declaration on workers health, Italy, www.who.int/occupational_health/Declarwh.

WHO (2007): Sixtieth World Health Assembly, apps.who.int/gb/ebwha/pdf.

Wind H, Gouttebarge V, Kuijer PP et al., (2009): Effect of Functional Capacity Evaluation information on the judgment of physicians about physical work ability in the context of disability claims. Int. Arch. Occup. Environ. Health. 82 (9): 1087-1096. 
الملخص العربي

\section{الإعاقة المتعلقة بالعمل بين العمال المصريين}

\section{هدى عبد المجيد الغمري و أماني صلاح محمد و دينا سليمان بلران 1 و محمد الحافظ نورى2...}

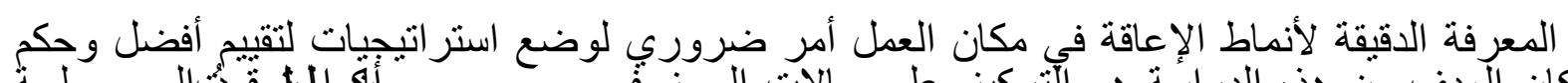

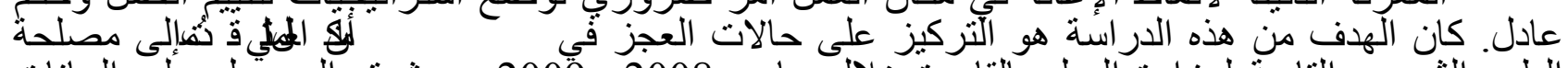

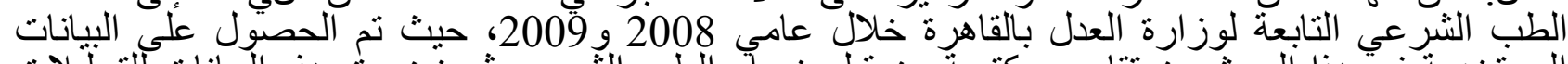

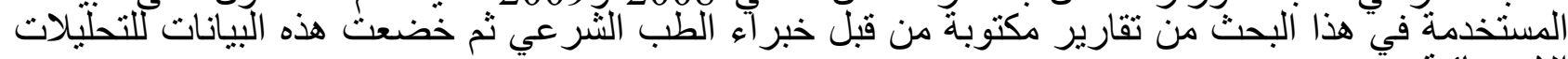

كُان إجمالي عدد حالات الإعاقة في مكان العمل في المؤسسات المختلفة 142 حالة وكانت المات المرحلة الإحصائية

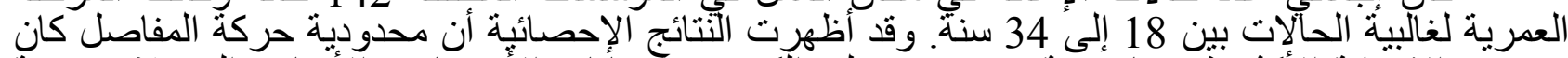

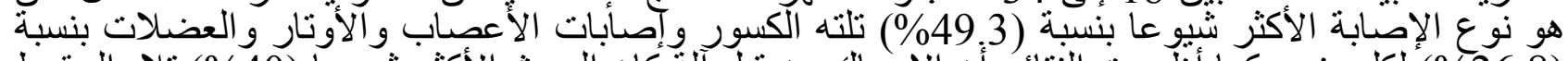

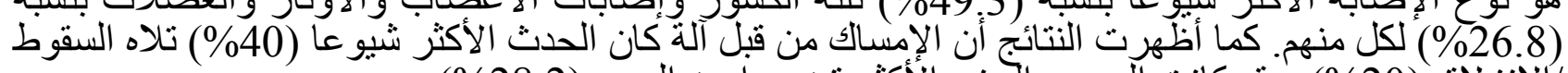

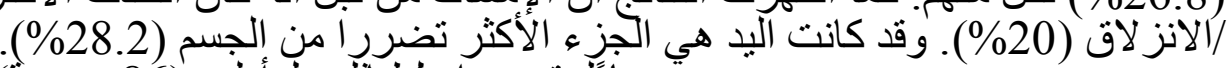

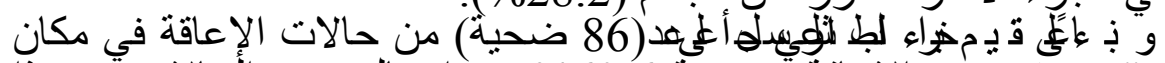

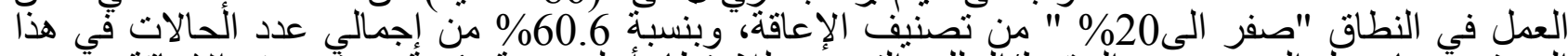

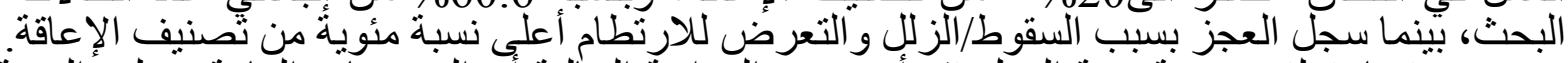

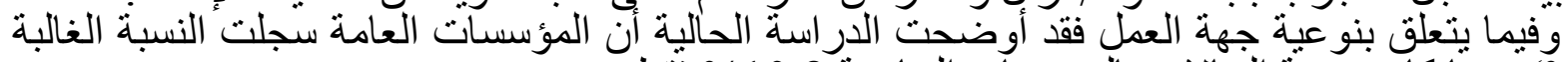

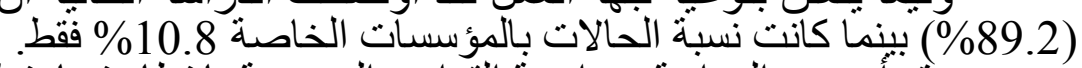

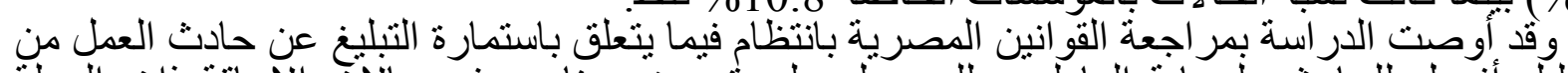

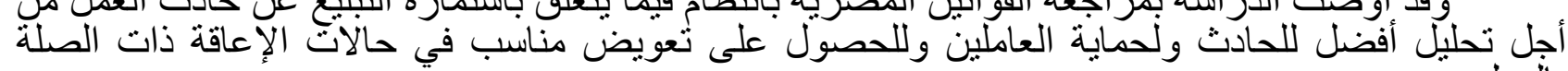
بالَعمل.

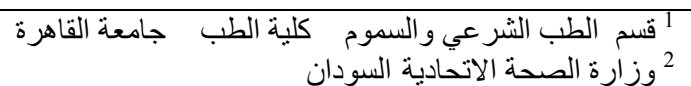

